\title{
Archaeological Testing of Site 41BL301 Bell County, Texas
}

Wayne C. Young

Follow this and additional works at: https://scholarworks.sfasu.edu/ita

Part of the American Material Culture Commons, Archaeological Anthropology Commons, Environmental Studies Commons, Other American Studies Commons, Other Arts and Humanities Commons, Other History of Art, Architecture, and Archaeology Commons, and the United States History Commons

Tell us how this article helped you.

This Article is brought to you for free and open access by the Center for Regional Heritage Research at SFA ScholarWorks. It has been accepted for inclusion in Index of Texas Archaeology: Open Access Gray Literature from the Lone Star State by an authorized editor of SFA ScholarWorks. For more information, please contact cdsscholarworks@sfasu.edu. 


\section{Archaeological Testing of Site 41BL301 Bell County, Texas}

\section{Licensing Statement}

This is a work produced for the Texas Department of Transportation (TxDOT) by the report producer. TxDOT and the report producer jointly own all rights, title, and interest in and to all intellectual property developed under TXDOT's contract with the report producer. The report may be cited and brief passages from this publication may be reproduced without permission provided that credit is given to both TxDOT and the report producer. Permission to reprint an entire chapter, section, figures or tables must be obtained in advance from either the Supervisor of the Archeological Studies Branch, Environmental Affairs Division, Texas Department of Transportation, 125 East 11th Street, Austin, Texas, 78701 or from the report producer. 
ARCHAEOLOGICAL TESTING OF SITE 41BL301

BELL COUNTY, TEXAS

BY

Wayne C. Young

Texas

State Department of Highways and Public Transportation Highway Design Division

June 1986 


\section{TABLE OF CONTENTS}

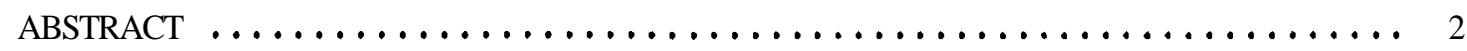

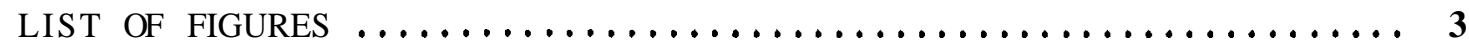

INTRODUCTION $\ldots \ldots \ldots \ldots \ldots \ldots \ldots \ldots \ldots \ldots \ldots \ldots \ldots \ldots \ldots \ldots \ldots \ldots \ldots$

SITE DESCRIPTION $\ldots \ldots \ldots \ldots \ldots \ldots \ldots \ldots \ldots \ldots \ldots \ldots \ldots \ldots \ldots \ldots \ldots \ldots \ldots$

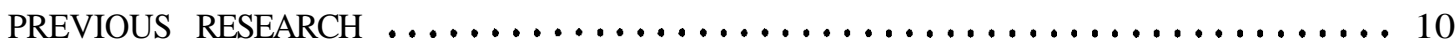

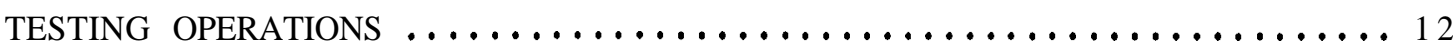

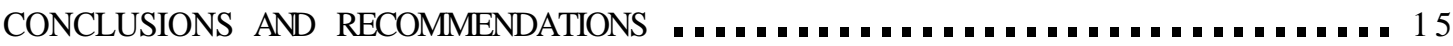

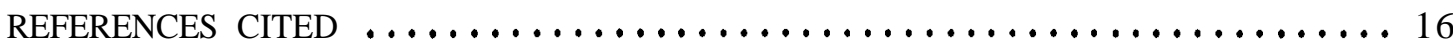




\section{ABSTRACT}

Testing of Site 41BL301 on FM 3467 in Bell County, Texas, was undertaken i n May 1986 to assess the site's potential for nomination as a State Archeological Landmark, and to determine site depth, cultural context and archaeological significance. The site is located along a second terrace on the south side of Nolan Creek in the western outskirts of Belton, Texas. The majority of the site lies outside the highway right-of-way along the terrace system. Results of the testing indicate that those portions of the site within the project limit contain a minimal prehistoric component--probably a 1 ithic procurement source--of unknown age which is largely limited to the present ground surface. Subsurface testing with a hand-excavated unit and a Gradall failed to locate buried components. 


\section{LIST OF FIGURES}

FIGURE 1. Location of Site 41BL301 in Bell County, Texas ........ 5

FIGURE 2. Cross-section through Site 41BL301 along centerline of

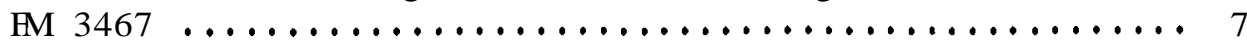

FIGURE 3. Soil Profiles of Gradall trenches excavated into Site 41BL301 ....................................... 9

FIGURE 4. Contour map of Site 41BL301 showing areas tested within

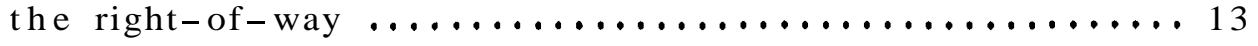




\section{INTRODUCTION}

Archaeological Site 41BL301 was recorded at the Texas Archeological Research Laboratory of the Balcones Research Center, The University of Texas at Austin, in May 1985 by a member of the State Department of Highways and Public Transportation (SDHPT) cultural resources staff. Following initial evaluation, further investigations and testing were conducted by Wayne C. Young of the SDHPT cultural resources staff with field-support assistance from the SDHPT District 9 Belton residency staff. Testing was conducted on May 27 and 28, 1986.

Testing of Site 41BL301 was performed under the auspices of the Memorandum of Understanding between the SDHPT and the Texas Antiquities Committee. The object of the test was to determine eligibility for State Archeological Landmark status and the cultural significance of the site. A total of 8 man-days was spent testing the site.

Site 41BL301 is located west of Belton, Texas, and east of Camp Kinsolving, and is along the south bank of Nolan Creek (Fig. 1). The site occupies the western limit of a major second terrace system along the south side of the creek and is located at the base of a limestone and flint bluff. Soils consist of a black clay overlying a reddish orange clay atop a light tan silty clay which extends to a depth of 4 meters beneath the present ground surface. Natural impacts on the site include slope wash and flooding from Nolan Creek during monumental floods . 
This Page Redacted Per THC Policy 


\section{SITE DESCRIPTION}

Site 41BL301 covers about 3 acres along a second terrace system on the south side of Nolan Creek in Bell County, Texas. The terrace is situated between a prominent limestone and flint bluff to the south and Nolan Creek to the north. A slight first terrace is present on the north side of the creek. The width ranges from 20 meters at the western $1 \mathrm{imits}$ where the proposed right-of-way crosses the terrace to 100 meters east of the highway limits. Most of the terrace system has been plowed in the past but is now planted in coastal Bermuda grass; it also has scattered native pecan trees.

The bluff area in the site vicinity is about $50 \mathrm{ft}$. higher than the terrace. It rises $50 \mathrm{ft}$. vertically in a 150-ft. horizontal extent, creating a steep slope. Much of the bluff area is exposed limestone and flint nodules, but small cedars and brush manage to grow in areas with soil deposits. The top of the bluff has been cleared and is covered in native grasses, with occasional cedars growing in a very thin soil mantle over limestone bedrock and very numerous flint nodules.

Figure 2 provides a profile along the centerline of the farm-to-market highway. The steepness of the bluff and the narrow width of the terrace are quite apparent in this illustration. The figure also illustsrates plans to place $20 \mathrm{ft}$. of $\mathrm{fi} 11$ atop the site within the right-of-way. During construction there will be no cutting in the area of the site. It should be mentioned that the right-of-way crosses the extreme western $1 \mathrm{imits}$ of the site and terrace. 


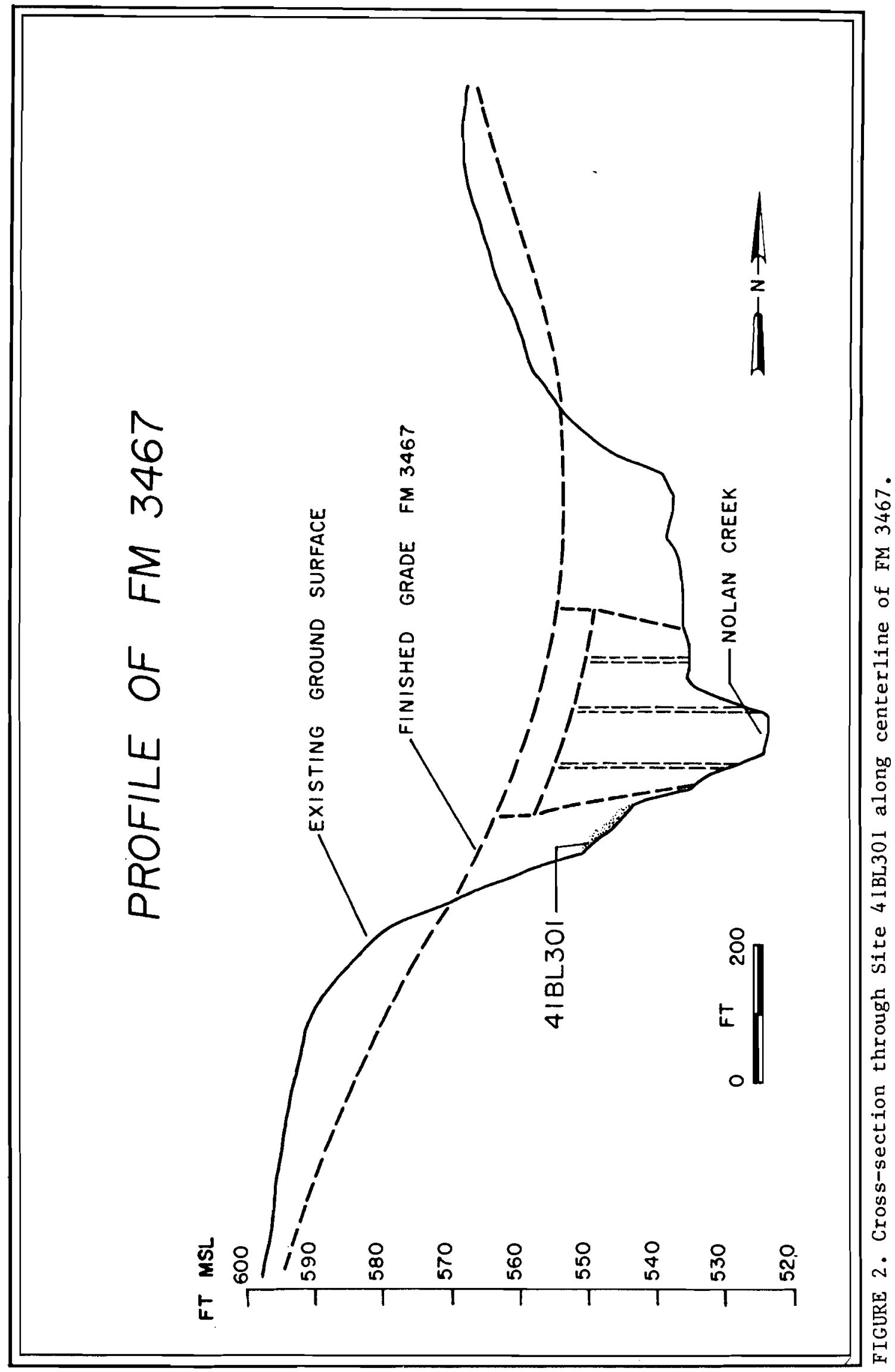


The ground surface of Site 41BL301 within the highway right-of-way was littered with limestone and natural flint slabs among the native grasses, cedars, and stunted brush. Noted on the surface during the 1985 survey were numerous flint flakes and 2 cores. Surface soils are a black clay common to Central Texas. The Gradall cuts within the rightof-way indicated that this soil was 60 to $70 \mathrm{~cm}$ thick and overlying a reddish orange clay with caliche gravels. This zone was 1.3 meters thick and overlying a zone of tan silty clay which extended to a minimum depth of 4 meters beneath the present ground surface (Fig. 3).

The highway construction over Site 41BL301 will involve removing the top of the bluff and placing it over the site area within the right-ofway. Highway construction will preserve rather than destroy the site by placing a $20-\mathrm{ft}$. thick layer of soil over the sparse cultural deposit at Site 41BL301. 


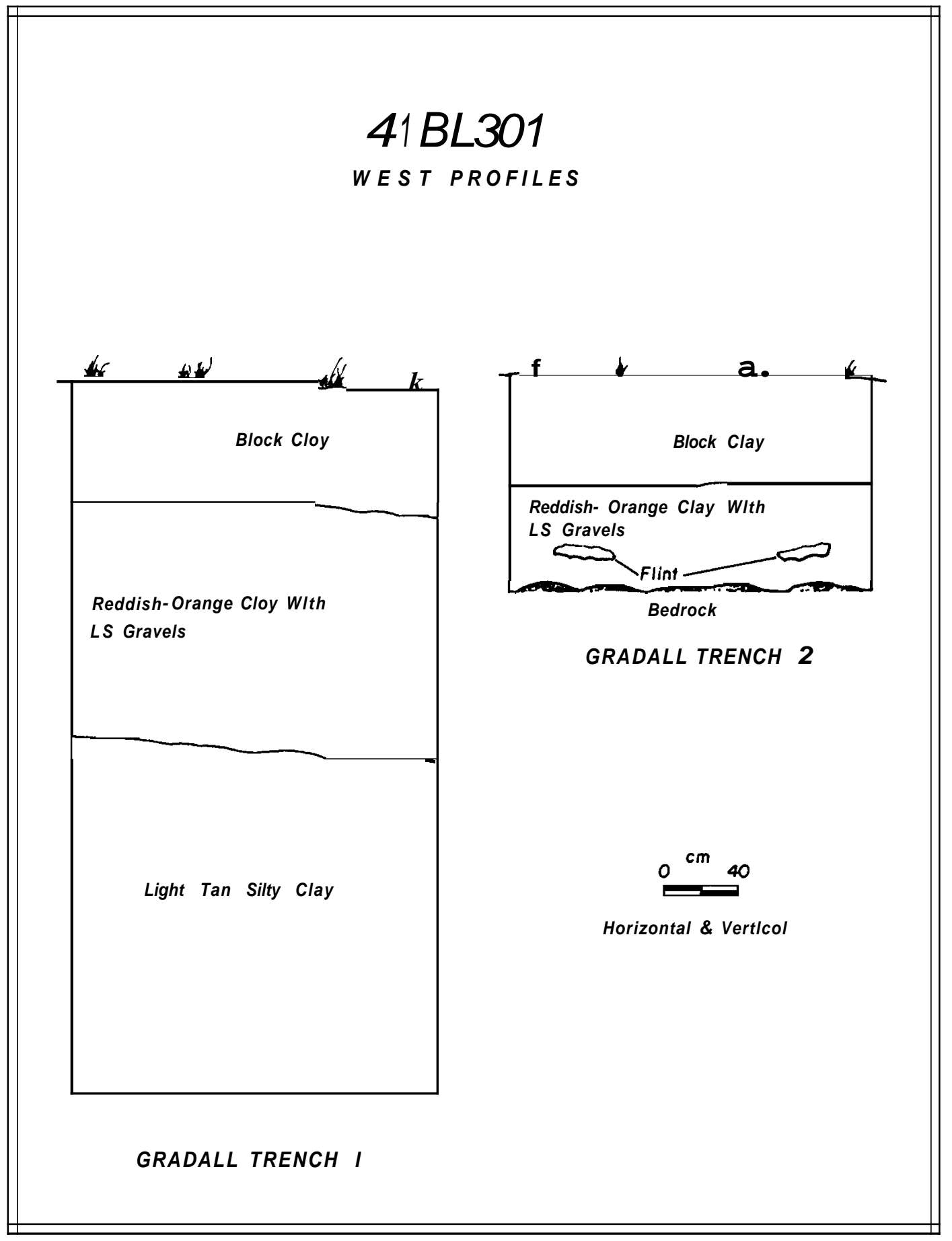

FGURE 3. Soil profiles of Gradall trenches excavated into Site 41BL301. 


\section{PREVIOUS RESEARCH}

A considerable amount of archaeological research has been performed in Bell County, Texas. The county is one in the easternmost tier of counties in Central Texas and has been the base of operation for the Bell County Archeological Society since the 1930s. The county also has seen the construction of large-scale federal projects including Fort Hood, Lake Belton, and Stillhouse Hollow Reservoir which allowed for archaeological investigations. Archaeologically, Bell County is one of the better known Central Texas counties and has provided significant information toward our understanding of prehistoric chronologies in this part of Texas.

Information on the prehistory of the county began to be published in the 1930s. Perhaps the earliest reported research was that of Jackson (1935). Several reports were published on the archaeology of Aycock Shelter (Watt 1936; Aynesworth 1936a, 1936b; Lux 1936). Russell (1936) provided an early report on the general archaeology of Bell County, and Watt (1937) reported on a burial site near Little River.

Any publications directly dealing with the archaeology of Bell County during the 1940s have esdaped the writer's attention, and it is assumed that there was a hiatus in research during this decade. The publication of research findings resumed during the 1950s, however.

Holden (1951) issued a report on stone beads from the county and Miller and Jelks (1952) reported on excavations at Belton Reservoir. Forrester (1957) reported an unknown type of implement from the county. 
During the 1960s some of the major sites in Bell County were excavated and reported. In 1962 Johnson reported on the survey of Stillhouse Hollow Reservoir (Johnson 1962). Shafer (1963) detailed the findings a the Youngsport Site, a major Early Archaic site in Central Texas. Shafer et al (1964) published the results of the 1962 testing in Belton Reservoir. Sorrow et al. (1967) detailed their excavations at Stillhouse Hollow Reservoir and presented the first local chronology for the county.

During the 1970s Shafer presented a paper on the late prehistory of the area (1971). Cochran (1974) reported on the Shetland Site. McCormick and Filson (1976) reported on a survey in Copperas Cove, and Dibble (1977) reported a survey on Fort Hood. Thomas (1978) presented an overview of the archaeological resources of Fort Hood.

The major work in bell County during the 1980s has been Fort Hood surveys. Carlson et al. (1983) appear to have produced the most recent publication dealing with the prehistory of Bell County. 


\section{TESTING OPERATIONS}

Archaeological investigation of Site 4 1BL301 consisted of surface observations, the hand excavation of 1 unit, and the machine excavation of 2 Gradall trenches. Test excavations were limited to the right-of-way area on the second terrace system.

Surface observations indicated a rather thin and uniform scatter of flint flakes and flint nodules within the right-of-way. There were no obvious concentrations of materials and no exposed features visible. With no indications other than a general scatter of prehistoric debitage to aid in selecting a location for a test unit, an area clear of brush 2 meters east of Centerline Station $89+00$ was chosen for testing and a 2 -meter square was staked out parallel to the centerline. The unit was excavated in arbitrary $10-\mathrm{cm}$ levels from the present ground surface (Fig. 4). All soils were screened through .25-in. mesh hardware cloth, and cultural materials were retained and bagged by square and level coordinates.

Level 1 of Test Unit 1 contained 2 small metal fragments, 1 core, and 53 flakes. Of the 53 flakes, 6 are primary decortication, 26 are secondary decortication, and 21 are interior flakes. The decortication series account for $60 \%$ of the total lithic debitage. No burned rock, features, bone, shell, or diagnostic artifacts were recovered.

Level 2 of Test Unit 1 was culturally sterile. Excavations were halted at $20 \mathrm{~cm}$ due to the lack of materials in this unit and the lack of deeper materials visible in the Gradall trenches. 


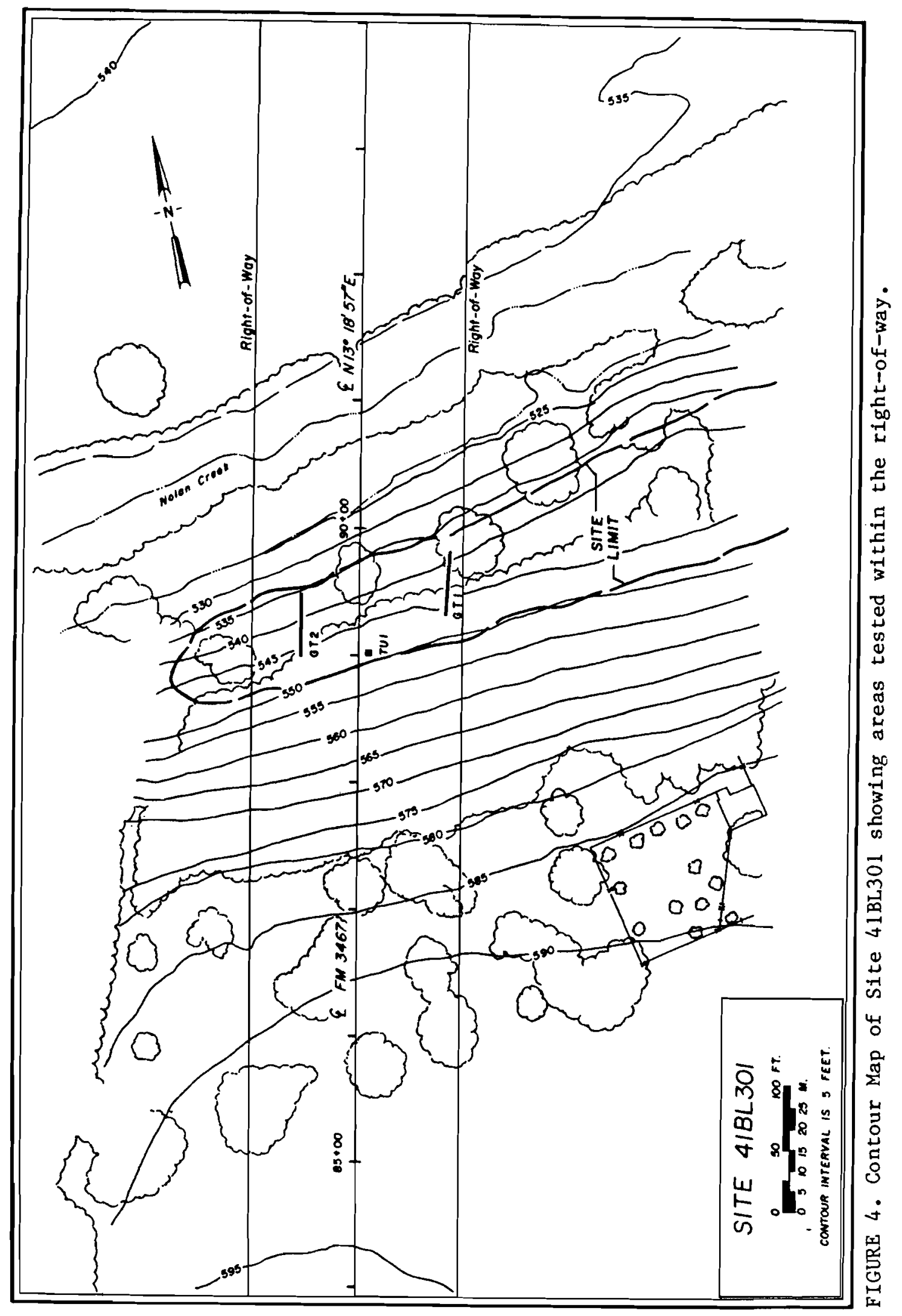


Gradall Trench 1 was placed on the eastern right-of-way and was excavated to check for buried cultural deposits. A 15-meter-long trench was dug to a depth of 4.25 meters and revealed no subsurface materials. The only prehistoric debitage in this trench was noted in the uppermost $5 \mathrm{~cm}$.

Gradall Trench 2 was placed 13.5 meters west of Test Unit 1 and was excavated to a depth of 1.2 meters. This trench also lacked any subsurface cultural debris but did contain several large flint nodules which had eroded from the bluff. These were found at a depth of 1 meter, or $20 \mathrm{~cm}$ above bedrock.

Excavations were halted after excavating the trenches and the test unit as there appeared to be no subsurface cultural components. The high percentage of decortication flakes $(60 \%)$ and the large amount of $\mathrm{flint}$ nodules at the site suggest that the site functioned primarily as a quarry locale and not a habitation site. No diagnostic artifacts were recovered to pinpoint the period of utilization. 


\section{CONCLUSIONS AND RECOMMENDATIONS}

Archaeological testing of a portion of 41BL301 within the right-of-way of $\mathrm{HM} 3467$ in Bell County has established that the portion of the site within the right-of-way is a low density, shallow quarry location of unknown age along the second terrace on the south side of Nolan Creek. Cultural materials appear to be limited to the surface and the uppermost 5 to $10 \mathrm{~cm}$ of soil deposits. Limited testing suggests that most of the lithic reduction of abundant flint nodules was concerned with early reduction and cortex removal. Under these circumstances, chances of recovering significant diagnostic material to date the utilization of the quarry area seem unlikely. Construction of the highway will place $20 \mathrm{ft}$. of fill over the site within the right-of-way and will not have an adverse affect on that portion of the site.

The sparsity of cultural materials recovered and observed negate the need for additional investigation at the site. Access to property outside'the right-of-way was not gained, so a determination of State Archeological Landmark status was not made for those portions of the site lying outside the right-of-way. No further investigation of Site 41BL301 within the right-of-way is recommended. 


\section{REFERENCES CITED}

Aynesworth, K. H.

1936a Biographic Studies of Twenty-One Skulls of the Central Texas Indians. Bulletin of the Central Texas Archeological Society 2:30-34.

1936b Flint Arrowhead Wounds of Bones as Shown in Skeletons in Central Texas. Bulletin of the Central Texas Archeological Society 2:74-80.

Carlson, David L., Fredrick Bruier, Henry Bruno, and Eli Mishuck 1983 Final Report on Statistically Representative Sample of Sites at West Ford Hood. Report submitted to U. S. Army by Science Applications, Inc. La Jolla, California.

Cochran, Joe F.

1974 The Shetland Site, Bell County, Texas. Paper presented at the annual meeting of the Texas Archeological Society. Dallas.

Dibble, David S.

1977 A Cultural Resource Survey of the Proposed Air Route Surveillance Radar Site. Fort Hood. Texas. Technical Bulletin 19. Texas Archeological Survey, The University of Texas at Austin.

Forrester, Robert E., Jr.

1957 Report on an Unknown Type of Implement. Bulletin of the Texas Archeological Society 18:121-126.

Holden, W. C. (Editor)

1951 Stone Beads from Bell County. Bulletin of the Texas Archeological Society 22:228.

Jackson, A. T.

1935 Ornaments of East Texas Indians. Bulletin of the Texas Archeological and Paleontological Society 7:11-28.

Johnson, LeRoy, Jr.

1962 Survey and Appraisal of the Archeological Resources of Stillhouse Hollow Reservoir on the Lampasas River, Bell County, Texas. Texas Archeological Salvage Project, University of Texas at Austin.

Lux, Konrad 1936

A Detailed Report on the Teeth and Supporting Structures as Found in Crania of Aycock Shelter. Bulletin of the Central Texas Archeological Society 2:39-42. 
McComick, O.F., and R. E. Filson

1976 A Report on Archaeological Investigations of Proposed Wastewater Treatment Facilities, Copperas Cove, Texas. Institute of Applied Sciences, North Texas State University, Denton.

Miller, E. O., and E. B. Jelks 1952 Archeological Excavations at the Belton Reservoir, Coryell County, Texas. Bulletin of the Texas Archeological andPaleontological Society 23:168-217.

Russe11, F. B.

1936 Archeology of Bell County. Bulletin of the Central Texas Archeological Society 2:49-51.

Shafer, Harry $\mathbf{J}$.

1963 Test Excavations at the Youngsport Site: A Stratified Terrace Site in Bell County, Texas. Bulletin of the Texas Archeological Society 34:57-81.

1971 Late Prehistory of Central Texas, 500 B.C.-1700 A.D. Paper presented at the 74 th annual meeting of the Texas Academy of Science. Nacogdoches.

Shafer, Harry J., Dee Ann Suhm, and J. Dan Scurlock 1964 An Investigation and Appraisal of the Archeological Resources of Belton Reservoir, Bell and Coryell Counties, Texas, 1962. Miscellaneous Papers 1. Texas Archeological Salvage Project, University of Texas at Austin.

Sorrow, William M., Harry J. Shafer, and Richard E. Ross

1967 Excavations at Stillhouse Hollow Reservoir. Papers of

- the Texas Archeological Salvage Project 11. The University of Texas at Austin.

Thomas, George B.

1978 A Survey and Assessment of the Archeological Resources of Fort Hood, Texas. Bulletin of the CXaS Archeological Society 49: 195-240.

Watt, Frank H.

1936 A Prehistoric Shelter Burial in Bell County, Texas. Bulletin of the Central Texas Archeological Society 2:4-27.

1937 A Gravel Pit Burial Near Little River. Bulletin of the Central Texas Archeolonical Society 3:80-82. 